\title{
Toward a Decolonial Global Ethics
}

\author{
Dr Robin Dunford, School of Humanities, University of Brighton
}

Acknowledgement: Thanks are due to Dr Michael Neu for his careful and constructive reading. Thanks also to the editors of Journal of Global Ethics and the anonymous referees for their excellent suggestions.

\begin{abstract}
:
This paper argues that decolonial theory can offer a distinctive and valuable ethical lens. Decolonial perspectives give rise to an ethics that stresses our fundamentally global responsibilities but is distinct from, and critical of, moral cosmopolitanism. Decolonial ethics shares with cosmopolitanism a refusal to circumscribe normative commitments on the basis of existing political and cultural boundaries. It differs from cosmopolitanism, though, by virtue of its rejection of the individualism and universalism of cosmopolitan thought. Where cosmopolitan approaches tend to articulate abstract principles developed from within a particular Western tradition, decolonial approaches reject abstract global designs in favour of inter-cultural dialogue amongst multiple people(s), including peoples who deem collective and nonhuman entities to be of fundamental moral importance. In addition, decolonial global ethics rejects universality in favour of "pluriversality".
\end{abstract}

Key words: Decolonial, Global Ethics, Cosmopolitanism, Pluriverse, Colonialism

\section{Toward a Decolonial Global Ethics}

This paper argues that decolonial theory can offer a distinctive and valuable ethical lens. Decolonial perspectives give rise to an ethics that is distinct from, and critical of, moral cosmopolitanism. Decolonial ethics shares with cosmopolitanism a refusal to circumscribe normative commitments on the basis of existing political and cultural boundaries. It differs from cosmopolitanism, though, by virtue of its rejection of 'individualism' and 'universality' - two 'elements' that 'are shared by all cosmopolitan positions' (Pogge, 1992, 48). Where cosmopolitan approaches tend to articulate abstract principles developed from within a particular Western tradition, decolonial approaches reject abstract global designs in favour of inter-cultural dialogue amongst multiple people(s), including peoples who deem collective and nonhuman entities to be of fundamental moral importance. In addition, decolonial global ethics rejects universality in favour of "pluriversality".

This paper serves two purposes. First, it introduces decolonial theory as a theoretical framework in global ethics. Second, it offers a distinctive reading of decolonial global ethics by reflecting on hitherto ignored tensions between two aspects of pluriversality and, relatedly, between two understandings of decoloniality. A value is pluriversal in a first, procedural sense, if it is constructed not through the universalisation of a particular perspective, but through dialogue across plural cultures and cosmovisions. In a second sense, pluriversality connotes a substantive value itself - the value of a world in which other worlds are possible. This value binds together equality and difference - people(s) have a right to inhabit their different worlds because they are 
equal. The pluriverse, from this substantive perspective, would be a world in which multiple cosmovisions, worldviews, practices and livelihoods co-exist, a world where no one particular way of living shuts down others. This tension between two different forms of pluriversality is related to a second tension between weaker and stronger readings of decolonial theory. When thinking in terms of the first form of pluriversality - pluriversal values as those that emerge from intercultural dialogue decolonial theory understands itself as offering an option that can take its place at the table alongside other options, which might include Westerncentric perspectives, liberal cosmopolitanism, and so on. This reading of decoloniality as an option risks blunting the critical power of decolonial ethics and leading toward a relativism of anything goes. When focusing on pluriversality as both a substantive value and a particular process of value formation, by contrast, decoloniality becomes an imperative, and explicitly rules out some other visions - including liberal cosmopolitan visions - of global ethics. When understood in this stronger form, I argue, decolonial global ethics provides an ethical lens fit to challenge the enduring legacies of colonialism.

There are two important caveats to the argument developed here. First, I do not present an exhaustive and definitive statement of decolonial ethics. Such a statement would be impossible, for decolonial ethics has emerged from, and must remain open to being shaped by, dialogues amongst millions of grassroots actors and activists. Moreover, I do not have space here to explore some important issues, such as the role global institutions might play in decolonial ethics (see, i.e., Grosfoguel, 2011, 30). Second, cosmopolitanism is an extremely broad church. This paper does not reject all cosmopolitan thought. It provides a critique of and alternative to those cosmopolitanisms that sit comfortably under Pogge's definition of moral cosmopolitanism as universalistic and individualistic. Though Pogge suggests that these features are shared by all cosmopolitan positions, 'vernacular' (Werbner, 2006), 'emancipatory' (Pieterse, 2006) and other cosmopolitanisms do not fit his definition. Indeed, Mignolo's 'cosmopolitan localism' (2011) is explicitly decolonial in

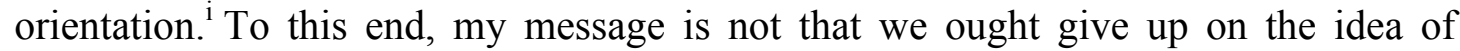
cosmopolitanism entirely. It is, rather, that decolonial global ethics - regardless of whether one describes it as an alternative cosmopolitanism or an alternative to cosmopolitanism - provides a plausible alternative to the universalistic and individualistic cosmopolitan thought that is currently prevalent in global ethics. This alternative is an important one. When rival - nationalist, communitarian, and society of states - approaches suggest that we have stronger commitments to those that are "close" to us, it is tempting to think that moral cosmopolitanism is the only framework that regards ethics as fundamentally global. For this reason Widdows $(2011,97)$ suggests that 'it makes a lot of sense for a global ethicist to endorse a cosmopolitan position of one form or another'. By showing that one can be a distinctly global ethicist without adopting the individualism and universalism of moral cosmopolitanism, decolonial ethics opens options, beyond the cosmopolitan canon, for a fundamentally global ethics.

The following section introduces decolonial thought and its claim that Western modernity, and the cosmopolitan values entwined with modernity, have an inextricable darker side - coloniality. It also suggests a "colonial matrix of power" persists today, and continues to underwrite the purportedly good things - including liberal-democratic institutions - that cosmopolitan theorists seek to globalise. If this is 
the case, universalistic and individualistic forms of cosmopolitan thought occlude and ultimately reproduce the colonial matrix of power. The third section outlines border thinking and pluriversality as distinctive features of decolonial global ethics. Finally, the fourth section analyses the tension between different forms of pluriversality and stronger and weaker readings of decoloniality, arguing for a stronger reading of decoloniality as an imperative, rather than an option.

\section{Coloniality as the Darker Side of Western Modernity}

The decolonial school (Alcoff, 2012; Castro-Gómez, 2007; Dussel, 2012; Escobar, 2004; Grosfoguel, 2011; Lugones, 2007; Maldonaldo-Torres, 2008; Mignolo, 2011; Quijano, 2007; Walsh, 2010) suggest that intersecting political, economic, cultural, racial, gender, epistemic and other hierarchies have shaped the world since the "discovery" of Latin America. These hierarchies - which together form a colonial matrix of power, and which persist beyond the end of formal colonial rule - are the inextricable darker side of modernity. Key to this matrix are particular values Christianity, civilisation, development, or liberal-Democracy - that have been imposed on others as universal and globally applicable designs. Different cosmovisions - ways of understanding the world - and different modes of living have been crushed, often violently, in the name of such particular perspectives masquerading as universal global designs. The decolonial school also reflects on what it means to decolonise, focusing on how inter-cultural dialogue amongst people and collective peoples on the subordinate side of colonial relations of power can unpick multiple, intersecting hierarchies and construct, in their place, a pluriversal world. Rather than offering a singular, universal vision of what counts as ethically valuable, pluriversality connotes a world in which different worlds can fit - a world in which multiple cosmovisions and livelihoods, including those threatened by the colonial matrix of power, can survive and thrive.

The distinctiveness of decolonial global ethics stems from an analysis of coloniality as the darker side of modernity. Whilst full justification would require the more extensive treatment that it has received elsewhere, the claim that coloniality is the darker side of modernity provides vital background for understanding decolonial ethics. Indeed, decolonial ethics emerged in response to five centuries of, and enduring legacies of, colonial rule, and explicitly rejects the idea that normative thinking can operate in a historical and political vacuum. This section thus offers a decolonial reading of coloniality, contrasting it with Westerncentric understandings of modernity implicit in Pagden, Held and Archibugi's emblematic version of cosmopolitan thought. According to Pagden,

it is hard to see how any form of cosmopolitanism can be made to address the difficulties of the modern world if it does not...begin where Kant...began, that is with some vision of a community of "the wise" whose views in the end triumph...In the modern world, it is equally hard to see, at least in the immediate future, that those views can be anything other than the reflection of the values of Western liberal democracies (Pagden, 2000, 19).

For Pagden, cosmopolitan values come from wise elites and travel, in one direction, from Western liberal-democracies to the rest. The presumption, here, is that Western 
enlightenment thought provides universal and globally salient values. Similarly, the liberal-democratic institutions of Western modernity provide a model for a cosmopolitan order. What is regarded as a particularly European history is simultaneously regarded as a universal and globally applicable model fit to address the 'difficulties of the modern world'.

Decolonial thought exposes the Westerncentrism of this account. Westerncentrism, here, not only refers to the global extension of an idea that has roots in a particular culture. Indeed, decolonial thought rejects the idea that there are distinct silos, be they communities or nations, with radically separate histories and cultures. Rather, Westerncentrism takes at least three often-related forms: historical internalism; universalism; and one-way diffusionism (see, i.e., Anievas and Nisancioglu, 2015). All three can be seen in the cosmopolitan democracy project articulated by Archibugi, Held and Marchetti.

First, historical internalism relates to understandings of modernity as an intraEuropean (and North American) phenomenon. Take Archibugi and Marchetti's (2009, 55) claim that 'until recently the effects of human actions were mostly contained within a defined territory'. The 'recent', here, refers to the $20^{\text {th }}$ Century processes of globalisation that have weakened the state and generated a need and opportunity for a cosmopolitan reconfiguration of democracy. This suggestion ignores that 'defined' territories, and the benefits of living in them, were constituted through the violent plunder of colonialism. Second, universalism arises as purportedly Western ideas and institutions are regarded as always-already globally salient. One example is the individualist and universalist conception of moral personhood that underpins Held's cosmopolitan democracy. Despite being 'intertwined with liberalism and the enlightenment' and 'tied to particular traditions and places', this conception is regarded to amount, even prior to dialogue, to a 'general', universal 'claim' (Held, $2002,25)$. Third, one-way diffusionism refers to the assumption of a uni-directional travel of ideas, practices, institutions and forms of historical and economic development from West to rest. One might think here of the project of 'globalising democracy' - rolling out a Western model of liberal democracy - through the international enforcement of development and state-building policies (Archibugi and Marchetti, 2009, 58).

Archibugi and Marchetti's historical internalism reflects broader understandings of the enlightenment and modernity as a uniquely European/Western experience. Voluminous work has asked Weber's (2001, xxviii) question of why 'in Western civilization, and in Western civilization only, cultural phenomena have appeared which...lie in a line of development having universal significance and value.' The assumption, here, is that the enlightenment values that inform cosmopolitan thought, and the "modern" institutions protecting these values, arose endogenously in Europe. What happens, though, if we shift geopolitical perspective away from Europe and towards the 'immense majority of humanity, the seventy-five percent of the world situated in the southern hemisphere, the excolonial world' (Dussel, 1995, 7)? This epistemic shift enables decolonial thought to counter Westerncentrism by highlighting both the globality of Western history and the provincialism of Western understandings (Chakrabarty, 2000). Key to this critique is the claim that, contra historical internalism, Western modernity was and continues to be produced through global coloniality. As a result, 'there is no modernity without coloniality, with the 
latter being constitutive of the former' (Escobar, 2004, 11). Modernity was intertwined with both formal colonialism and coloniality, understood as the set of hierarchies that emerged with, and have continued beyond, colonial rule. The claim here is that coloniality, rather than being an accidental and ultimately separable byproduct of modernity, is constitutive of modernity. One cannot, therefore, simply take things one likes from modernity whilst leaving behind its coloniality. The oneway diffusion of Western modernity advocated in cosmopolitan thought is thus neither possible nor desirable.

In what way is coloniality constitutive of modernity? Coloniality was constitutive of the emergence first, of a capitalist modernity, second, of modern liberal-democratic institutions, and third, of enlightenment knowledge formations. Key, here, was the accidental "discovery" of Latin America. This "discovery" and subsequent conquest and colonisation mark, for the decolonial school, the 'birthdate of modernity' (Dussel, 1995, 11).

With the conquest of the societies and cultures which inhabit what today is called Latin America, began the constitution of a new world order, culminating, five hundred years later, in a global power covering the whole planet (Quijano, 2007, 168).

By 1650, the continent's population had gone from around 90 million to 10 million (Dussel, 1995). Why, though, was this extraordinary death and destruction constitutive of modernity? I focus here on how coloniality is constitutive of capitalist modernity and a political modernity combining (liberal) individual rights and democratic government, before highlighting how enlightenment knowledge formations are bound up with epistemic forms of coloniality.

Decolonial theory joins World Systems Theory in suggesting that colonialism was constitutive of capitalist modernity.

Europe did not pull itself up by its own economic bootstraps, and certainly not thanks to any kind of European "exceptionalism" of rationality, institutions, entrepreneurship, technology...instead Europe used its American money to muscle in and benefit from Asian production, markets, trade (Frank, 1998, 5).

Puerto Rico - the rich port, Argentina (from argentum - silver), and the Gold Coast in Panama were just some of the places from which precious metals were extracted (Dussel, 1995). The resources extracted - at great cost to workers enslaved in mines and people(s) dispossessed from land - were used to buy goods in Eastern markets. The discovery of gold, the 'extirpation, enslavement and entombment in mines of the aboriginal population', together with 'the turning of Africa into a warren for the commercial hunting of black skins' all 'signalised the rosy dawn of the era of capitalist production' (Marx, 1906, 823). Without this plunder, the accumulation of resources so central to the birth and reproduction of capitalism would not have been possible. Colonialism was constitutive of capitalist modernity.

Second, coloniality was constitutive of liberal-democratic political institutions. Democratic government and liberal rights, in particular rights to private property, can 
be contradictory. For Locke, man (and he meant man) had an inalienable right to property. He also thought that man, being free and equal, ought to have a say in and consent to government. Locke was, however, writing in a context in which only a minority had private property. Were those without property given an equal say in government, one would presume that they would radically redistribute property, and hence violate those inalienable rights to property. Locke therefore

had to show how society could be based on the principles of private property and government by consent in the absence of a majority of individuals supporting such developments, or, conversely, how the majority of the population could be convinced to establish and maintain such a polity (Jahn, 2013, 44).

In addressing this paradox, Locke gave the international politics of colonialism 'a crucial role in the constitution of domestic liberalism' (Jahn, 2013, 48). As Locke put it,

there are still great tracts of ground to be found, which (the inhabitants thereof not having joined with the rest of mankind, in the consent of the use of their common money) lie waste, and are more than the people who dwell on it do, or can make use of, and so still lie in common (Locke, 1988, 2:45).

Land in the Americas remained common because, in roaming across land, indigenous peoples had not mixed labour with land and hence, according to Locke's parochially produced but purportedly universal and globally salient account, had not acquired the land as inalienable property. This "empty" land was given to people leaving in search of a better life in the colonies and used to extract resources that would drive economic growth. In settler colonies, the appropriation of land from indigenous peoples, combined with the widespread destruction of those peoples and their cosmovisions concerning the collective stewardship of territory, ensured a wide distribution of, and common interest in the protection of, individual private property. It was only through this plunder and racialised redistribution that democratic principles could be combined with liberal rights. 'There was no need to fear revolution and hence universal franchise was generally introduced earlier in settler societies' (Jahn, 2013, 65). In Europe, over time, the economic growth enabled by colonialism led to a wider distribution of property, an enlarged middle class, and a mutual 'interest in expropriating foreign land', enabling the vote to be extended gradually over time (Jahn, 2013, 64). In both cases, coloniality was vital in enabling democratic government to coexist with liberal property rights. Coloniality was thus constitutive of the possibility of liberal-democratic institutions.

Third, coloniality is bound up with enlightenment knowledge formations. Decolonial thought focuses on epistemic forms of coloniality. Epistemic coloniality refers, in part, to hierarchies according to which Western knowledge and Western history is universally salient, whilst knowledges and histories from the other side of the colonial divide are provincial. To study the West would be to study general laws of development or universal principles of modernisation, but to study the South or East would be to study an "area" or a "culture" that produces data applicable only to a limited portion of the world. The coloniality of knowledge refers also to the form of 
knowledge construction in enlightenment thought. Rather than acknowledging that thought happens from a geo-political location and involves an embodied subject with a history, culture, social structure and feelings that may inflect their thought, enlightenment thought works to 'dissociate the subject from all bodies and territories; that is, to empty the subject of all spatial or temporal dimensions'. In thinking from a non-place, the disembodied thinker is able to 'speak beyond all the spatio-temporal limits of the cartography of social power' (Grosfoguel, 2012, 88; see also CastroGómez, 2007 and Maldonaldo-Torres, 2008). It then becomes possible to imagine that ideas, values, practices and institutions that have a particular history can be, and ought to be, imposed as global, universal designs (Mignolo, 2000).

The content of un-located, disembodied and hence universal knowledges can and has varied. What they have in common is that their universalisation shuts down alternative ways of knowing. The universalisation of Locke's particular understanding of property shut down alternative understandings of how to relate to land/territory. Similarly, the universalisation of a Baconian view of nature as something to be mastered and exploited for human use through techno-scientific forms of knowledge a view that remains prevalent in many visions of perpetual development and endless economic growth - shuts down Aymara, Quechua and other notions of Sumak

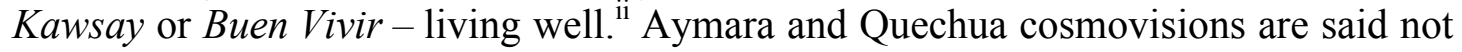
to contain the idea of a separation between humans and nature - a separation that makes it possible to think, with Bacon, that nature is there to be exploited for human use. Moreover, Sumak Kawsay contrasts with visions of perpetual development and growth insofar as it refers to living well - not better than others and not necessarily better than before (see Gudynas, 2011 and Walsh, 2010). Rather than being appreciated as different forms of knowledge based on different cosmovisions, these knowledges are locked in a hierarchical relationship. The Baconian, techno-scientific view of nature is thought from a particular position, yet has been elevated, without dialogue and exchange across cosmovisions, to the status of an already-universal global design, fit for imposition on societies elsewhere. 'At best', Quechua, Aymara and indigenous American perspectives, as perspectives from the other side of the colonial divide, provide 'practical and local forms of knowledge', subordinate to the West's purportedly universal and globally applicable knowledge' (Santos, Nunes and Meneses, 2007, xxxv). At worst, they represent uncivilised, backward worldviews; obstacles to progress that must be destroyed.

Decolonial thought links epistemic hierarchies with economic, military, political and other hierarchies in a "colonial matrix of power". The conflation of "the concrete hegemony derived from' Western power and a form of thought that portends 'abstract universality' (Dussel, 2000, 471) gives Western 'local knowledges and histories' the status of 'global designs', valid, applicable, and ultimately enforced everywhere (Mignolo, 2000, 17). The global designs that have been enforced over time have varied, but what they have in common is that they universalised a particular notion of what is good, valuable, or appropriate. As Grosfoguel puts it:

The imposition of Christianity in order to convert the so-called savages and barbarians in the 16th century, followed by the imposition of "white man's burden" and "civilizing mission" in the 18th and 19th century, the imposition of the "developmentalist project" in the 20th century and, more recently, the imperial project of military 
interventions under the rhetoric of "democracy" and "human rights" in the 21 st century, have all been imposed by militarism and violence under the rhetoric of modernity, of saving the other from its own barbarianism (Grosfoguel, 2011, 25)

This universalisation of local knowledge not only generates great violence, but also threatens, as indicated above, the knowledges and cosmovisions of others. In this sense, colonial encounters not only amount to the killing of huge numbers of people. They also constitute a form of epistemicide. Enlightenment forms of knowledge, based on the presumed universality of disembodied, placeless thought, are integral to this epistemicide.

To sum up, for the decolonial school, (global) coloniality is constitutive of (Western) modernity. Capitalism and liberal-democratic institutions were only possible through the colonial encounter, whilst enlightenment knowledge production, with its emphasis on disembodied universality, was bound up with the colonial imposition of particular perspectives set up as global designs. Modernity, then, is inseparable from a colonial matrix of power - an 'intersectionality of multiple, heterogeneous global hierarchies (heterachies) of sexual, political, gender, epistemic, economic, spiritual, linguistic and racial forms of domination and exploitation' (Grosfoguel, 2011, 11). This matrix classifies people, and treats them differently according to 'culture, religion, colour and continent' (Mignolo, 2011, 221).

This colonial matrix of power persists after formal colonial rule. Poverty and inequality operate along racialised, gendered and geopolitical lines, legacies of colonial rule are felt in contemporary forms of conflict and in so-called state "failure", and the export of liberal-democratic institutions of modernity continue to be outlined as a remedy (see Wai, 2012). Cultural hierarchies - which also operate along racialised, gendered and geopolitical lines - also remain, with indigenous art likely to be shown in a gallery showcasing "culture", rather than high art. Epistemic hierarchies, too, remain. One might think, here, of accounts of how global human rights norms are made to fit with "local cultures" by actors in the global South, without attention being paid to how these "local" actors also transform meanings and understandings of global rights (see Dunford, 2017). The colonial matrix of power also continues to constitute the liberal democracies of the West. Cheap food and cheap consumer goods are available in the West as a result of the extraction of natural resources, the destruction of peasant, indigenous and other livelihoods, and a racialised and gendered division of global labour. With a decreasing proportion of income going to labour, and with "ordinary" workers feeling the pinch of rising inequality, stagnant wages, deepening austerity, and a reduction of public services, these cheap goods, together with the vilification of racialised migrants, continue to underwrite liberal-democratic compromises.

Acknowledging coloniality as the still-present darker side of modernity raises questions for calls for the globalisation of the values and institutional practices that constitute Western modernity. If the emergence and reproduction of modern Western values and institutions depend on exploitation elsewhere then - contra Archibugi, Held and Pagden - they should not serve as a global model, and a different, decolonial global ethics is required. 


\section{Decolonial Global Ethics}

This section explores how decolonial reflections on, and responses to, coloniality as the darker side of modernity give rise to a distinctive global ethics. Given that coloniality involves particular perspectives being imposed as global designs, there may be a temptation to think that decolonial ethics would reject any global agenda on the basis that it will inevitably crush differences and reinforce coloniality. Calls for a world in which diverse, purportedly separate "cultures" are isolated and left alone do not, however, challenge the colonial matrix of power. Not only do they ignore the interconnectedness of different parts of the world, and hence sidestep the question of duties of redress for past and ongoing injustices. They also reinforce epistemic hierarchies rendering those on the underside of the colonial difference able to develop ideas of only "local" significance. Challenging the colonial matrix of power is a global project, meaning that decolonial ethics is and must be globally minded. It differs from cosmopolitan global ethics, however, in several important respects, of which I shall focus on two: border thinking and pluriversality.

\section{Border Thinking}

Reflecting the enlightenment knowledge formations criticised by decolonial theory, cosmopolitan thought tends to think in abstract universalist terms, without reflecting on the geopolitical location of the person who is speaking. Moreover, with notable exceptions including Sen's (2009, xii) self-proclaimed 'unusual' and 'eccentric' approach, cosmopolitan global ethics tends to think with a tradition of thought running through 'Aristotle, Stoics, Renaissance humanism, Kant, Rawls, Habermas' (Pieterse, 2006, 1251). Whilst the poor and the marginalised are often the object of cosmopolitan theorising, they are very rarely taken seriously as potential producers of theory and knowledge, or as potential agents of change. ${ }^{\text {iii }}$ As Deveaux $(2015,127$; see also Dussel, 2013) puts it, cosmopolitan work on global justice is 'marked by an absence of attention to the perspectives, aspirations, and political strategies of poor communities'. Decolonial thought, by contrast, begins from what it calls the "borders" or "margins". This sub-section shall explore what this means and explain why it results in a rejection of the individualism of moral cosmopolitanism.

Though coloniality has led to the destruction of cosmovisions and livelihoods, there remain

present-day cultures that predate European modernity, that have developed together with it, and that have survived until the present with enough human potential to give birth to a cultural plurality that will emerge after modernity (Dussel, 2002, 234).

To think from the borders is to think with these 'subaltern knowledges and cultural practices worldwide that modernity itself shunned, suppressed, made invisible and disqualified' (Escobar, 2004, 3). So doing means taking seriously as producers of knowledge those marginalised individuals, communities and traditions. 'Voices of the south must be heard', Maldonaldo-Torres $(2008,250)$ argues, not just 'because we presume or have 'faith' in the equal value of other cultures... but because the centuries old experience of coloniality and dehumanization provides colonized subjects with important perspectives'. One's geopolitical position and experience plays a role in 
shaping thought, and taking those on the receiving end of colonial forms of domination as producers of knowledge will mean understanding better, and being able to respond better to, legacies of colonial rule. Decolonial thought thus gives 'a preferential option for the condemned of the earth' by placing at its centre 'the questions, concerns and proposals for decolonization that emerge in the underside of the modern world' (Maldonaldo-Torres, 2008, 246).

Thinking from the borders not only involves giving this 'preferential option' to those on the receiving end of colonial rule. As Mignolo (2011, xiii) points out, 'the borders relate 'not to where you reside but where you dwell' (Mignolo, 2011, xiii). In other words, it relates not to where you happen to be, or where you are from, but to the perspective from which you think. Much as it is possible for someone residing in a marginalised community to adopt the worldview of the coloniser, it is possible for someone in a distant location to attempt to think from the geo-epistemic perspective of those threatened by global coloniality. To do so, however, would require engaging with, listening to, and responding to the actually-existing voices of people attempting to challenge colonial legacies. It is insufficient - as is common in cosmopolitan global ethics (e.g. Caney, 2015, 51) - to merely 'imagine' that you are in their position, only to draw exclusively on the Western canon, and not engage with marginalised actors as producers of moral theory.

Starting from the borders leads to a further notable difference between decolonial and cosmopolitan global ethics. The moral cosmopolitanism to which decolonial thought offers an alternative identifies individual persons as the only unit worthy of fundamental moral concern. Other being(s) - mother nature, communities, and so on, can be only of derivative concern on the basis that they are valued by, and/or support and realise the rights of, the individuals that ultimately matter. Some of the cosmovisions that operate at the borders have different understandings of what is of fundamental moral significance. There are, for instance, indigenous cultures in SubSaharan Africa that embrace the notion of ubuntu, that a person is a person only through other people, and hence deem the community to be of fundamental concern (Metz, 2014). Aymara and Quechua cosmovisions discussed earlier emphasise Sumak Kawsay, living well in harmony with Pachamama - Mother Nature - and the community. Given that these different perceptions of fundamental moral importance exist, decolonial ethics refuses to specify in advance what counts as worthy of such importance. To settle this question in advance serves only to exclude some positions in the name of a particular, individualistic value that is projected as a universal and global design. As such, it would reproduce epistemic forms of coloniality in which only some are able to speak for what is universally and globally significant. ${ }^{\text {iv }}$

Despite this rejection of individualism, decolonial ethics does not revert to a communitarian position according to which different cultures have their own isolated value systems and normative standards. The borderlands are already inflected with global processes. They are, after all, borderlands - places where a global form of coloniality is felt as domination, dispossession and potential epistemicide. The borders, then, provide an epistemic location from which to develop a critique 'of modernity from the geo-political experiences and memories of coloniality' (Grosfoguel, 2011, 24). To think from the borders is, moreover, to think with clashing perspectives. It is to bring into productive dissonance and develop a critical perspective on both modernity and the livelihoods and cosmovisons that it threatens. 
In this sense it is not anti-modern but transmodern - it involves thinking beyond modernity from the perspective of its borders (Dussel, 2012). One might think, for instance, of the way in which Zapatistas combine indigenous comsovisions and Marxist perspectives in a manner that 'remaps Marxism, thirdworldism, and indigenism, without being either of them' (Escobar, 2007, 188). Moreover, decolonial thought does not end with thinking from the borders. Rather, border thinking forms part of a broader, transnational project of inter-cultural dialogue. Coloniality is global in scope, as are the dynamics that destroy livelihoods - the resource extraction and appropriation that threatens indigenous livelihoods, the labour regulations harming workers, and the land grabs that undermine peasant livelihoods. Moreover, epistemic coloniality involves framing certain knowledges and understandings as parochial and merely "local", whilst framing others as rational, universal and global. Overcoming epistemic hierarchies means taking seriously as producers of globally salient knowledge those shunned by modernity. Key, then, is constructing a set of global understandings in a different way - a way that does not involve the one-way diffusion of locally produced and yet purportedly universal global designs. It is here that we meet the idea of pluriversality.

\section{Pluriversality}

Pluriversality refers, first, to the way in which a value is constructed and second, to a particular value of a world in which many worlds fit. As indicated earlier, universal values are constructed from a particular place, and yet deemed global in significance. Recall Held's $(2002,25)$ individualism, which is 'intertwined with liberalism and the enlightenment', 'tied to particular traditions and places', and yet regarded to amount, prior to democratic dialogue, to a 'general' and universal claim. Pluriversal values, by contrast, are a product of inter-cultural dialogue. A value is pluriversal insofar as it is constructed in a manner that takes seriously, shows respect for, and emerges from communication and exchange across multiple places, cultures and cosmovisions." This dialogue can involve forms of communication ranging from argument and discussion to performance and ceremony. Such communication, together with respectful translation across cultures and cosmovisions, can foster commonality, as people share stories of common forms of oppression. It can also develop values that have global significance not by virtue of an already-existing universality that can be articulated from one particular place, but on the basis of resonances amongst, translation across and the construction of common understandings amongst multiple positions.

Pluriversal dialogue is emphatically not something that an individual can perform through a thought experiment or imagined dialogue. To attempt to do so would return to a view that one can think inclusively - and think something that is universally valid - from one place. This would go against the decolonial commitment to take seriously as sources of knowledge those individuals and communities that have been on the receiving end of colonial domination. Pluriversal dialogue refers to real dialogue across a range of existing cultures and comsovisions. Indeed, the idea of pluriversal dialogue has emerged from attempts to foster such dialogue. One might think, here, of the dialogues across indigenous and Marxist traditions that helped construct the Zapatista movement (Mignolo 2011), dialogues across indigenous, peasant, pastoralist and fisherfolk cultures in the food sovereignty movement (Martínez-Torres and Rosset, 2014), and feminist dialogic practice in the World Social Forum (Leinius, 
2014; Conway and Singh, 2011). Moreover, pluriversal dialogue is not solely oriented towards consensus. Those involved in dialogue may include indigenous groups 'who want disengagement and autonomy more than anything else' (Alcoff, 2012, 64). In order to respect the autonomy of indigenous worlds, which might be governed in different ways and by different authorities, pluriversal dialogue can involve 'letting plurality stand, allowing convergence and cooperation to emerge in an unforced way, and rejecting the need for consensus-decision making' (Conway and Singh, 2009, 74). In this regard, pluriversal dialogue can be 'oriented towards defending localised lifeprojects and life spaces' (Conway and Singh, 2011, 698), with a view to constructing a world in which the worlds of indigenous peoples, amongst others, fit.

It is here that we meet the second aspect of pluriversality. Pluriversality connotes a value of, as articulated by the Zapatistas, "a world in which many worlds fit" or "a world in which many worlds are possible". Global coloniality threatens the survival of multiple worlds, be they the worlds of peasant farmers, indigenous peoples or others. Worlds other than the world of Christianity, then civilisation, then development, and now rapacious and environmentally destructive economic growth are impossible for many, especially for those without the privilege of being able to purchase an alternative "lifestyle". A pluriversal world would be a world where indigenous peoples, so often threatened with displacement, would cease to be prevented from living from their territory, whilst peasants would be supported in working the land to produce their own food on their own territory, provided these practices do not shut down those other worlds that, in turn, do not shut down alternatives. A particular way of living, policy, institutional practice, or value is compatible with a pluriverse if it allows other worlds to survive and thrive, and incompatible if it inevitably involves the destruction of other life-worlds.

This principle is based on and grounded in an understanding of the inseparability of equality and difference. 'A world in which many worlds are possible...means that people and communities have the right to be different precisely because we are all equals' (Mignolo, 2000, 311; Maldonaldo-Torres, 2008, 231). If we don't take difference seriously, and do not take seriously those that consider Pachamama to be of fundamental ethical importance, then we do not treat these peoples as equals. If we suggest that different livelihoods need to be overcome in the name of a form of development that the people affected do not demand, then we are not treating them as equals. To treat people as equals, then, is to take seriously difference and ensure a world in which many different worlds fit. It is also, as Dussel (2013, xvi) argues, 'grounded in the daily life and the dominant models prevalent in that context' - in the very experience of injustice in the face of the destruction of multiple worlds. To this end, pluriversality is also a response to experiences, discussed in the first section, of dispossession, domination, and epistemicide in the face of the longstanding and enduring colonial matrix of power.

\section{Tensions in Decolonial Global Ethics: Toward a Decolonial Imperative ${ }^{\text {vi }}$}

Decolonial ethics is not without its tensions, some of which I explore in this section. In principle, the above two aspects of pluriversality cut in different directions. The pluriversal as that which is formed through inter-cultural dialogue points in the direction of a dialogue in which positions are not excluded in advance (even if this dialogue may take place, initially at least, only amongst the oppressed), and in which 
no particular standard or value is valid in advance of dialogue. ${ }^{\text {vii }}$ Taken alone, this form of pluriversality raises questions. Does intercultural dialogue have any limits or constraints? Are values justified solely by virtue of having emerged through intercultural dialogue, or is it possible for a value to be wrong, normatively speaking, despite emerging from this process? Are any and all views allowed to the table, or ought certain views be rejected? What about those views that reproduce colonial narratives or values that have done so much to silence, undermine and oppress those on the underside of the colonial matrix of power? Taken alone, this aspect of pluriversality cannot provide an account of whether there are views, practices, and modes of engagement that should not be allowed in discussion. Nor can it rule out, as illegitimate, views, values, practices or policies that, despite emerging from discussion, may nonetheless go on to oppress others.

It is here that pluriversality as a value enters. Pluriversality as a value suggests that practices, worldviews, values, or policies are legitimate only if they remain compatible with the existence of other worlds. In this sense, pluriversality sets a standard of legitimacy that would judge as morally wrong any worldview, value or practice that does not accept the existence of, or that works to shut down, other worlds. That is not necessarily to say, though, that those holding such views ought to be excluded from dialogue.

There is a tension, then, between the two aspects of pluriversality. Giving ultimate priority to one aspect cannot solve this tension. Without any reflection on its emergence from pluriversal dialogue, the substantive value of pluriversality would become a new abstract, already-universal design, and would undermine all commitment to taking seriously as producers of knowledge those that are marginalised. Without the substantive value, there is no way of identifying why a dialogue that takes seriously multiple cosmovisions is a morally good thing. Nor would there be any way of casting any judgment on or identifying as morally wrong certain visions - racist visions, sexist visions, visions that advocate a form of modernity that inevitably reproduces coloniality. Both aspects of pluriversality must remain, and decolonial global ethics must find ways of navigating (if not resolving) any tension between them.

It will be for pluriversal dialogue to find ways of navigating this potentially irresolvable tension. To offer some ideas to any such discussion, it is worth noting that the substantive value of pluriversality has emerged, in practice, through pluriversal exchanges in indigenous, peasant (Martinez-Torres and Rosset, 2014), feminist (Leinius, 2014) and World Social Forum praxis (Conway and Singh, 2011). Having emerged as an abstract value through concrete, intercultural dialogue, it can, in turn, retrospectively account for why it is that such dialogue is, normatively speaking, a good thing. One might also note that the abstract value of a world in which other worlds are possible does not give rise immediately to concrete values, practices, policies and attitudes. Understanding what kind of practices, policies, and modes of behaving and living enable other worlds to exist, and fostering the kind of respect for other worlds that such practices and ways of living may require, requires pluriversal dialogue, for it is through such exchanges that it will become apparent that certain demands and ways of living can and do result in the oppression of others. Both aspects of pluriversality can thus be mutually enriching in practice, despite the potential for tension between them. Whilst there is not room to introduce them in 
depth here, any readers inclined to think that this tension makes decolonial ethics unworkable, hopelessly idealistic and of no use in the "real world" would be advised to explore the practices of the social movements that navigate these tensions.

Related to this difference between the two aspects of pluriversality are tensions between decoloniality as an option and decoloniality as an imperative. For Mignolo,

there will be no place for one option to pretend to be the option. The decolonial option is not aiming to be the one. It is just an option that, beyond asserting itself as such, makes clear that all the rest are also options (Mignolo 2011, 21).

Similarly,

what we put on the table is an option to be embraced by all those who find in the option(s) a response to his or her concern and who will actively engage, politically and epistemically, to advance projects of epistemic and subjective decolonisation and in building communal futures (Mignolo, 2011, xxvii).

This weaker version of decoloniality appears not to rule out, as incompatible with decolonial global ethics, other visions. 'Western civilization' would then, Mignolo (2011, 176) suggests, 'merely be one among many options, and not the one guide to rule the many.' The decolonial option serves to add another option to the table. It does not necessarily reject Western modernity, liberal cosmopolitanism, or other positions, provided that they, too, present themselves only as an option. When understanding pluriversality in terms of its procedural aspect, this makes perfect sense. It would be wrong to set out, in advance, one option as an imperative, as one we ought to follow, albeit in different ways. The worry with this weaker version, however, is that it risks 'losing the ability for critique' (Alcoff, 2012, 6) and becoming a relativism of anything goes.

For Grosfoguel $(2012,101)$, by contrast, pluriversality is not 'a relativism of anything goes'. Similarly, for Dussel $(2012,19)$, a decolonial perspective does 'not presuppose the illusion of a non-existent symmetry between cultures'. Instead, it acknowledges that some cultures, cosmovisions, and livelihoods are systematically threatened by others and cannot survive in the face of cosmovisions and lifestyles that are inextricably tied to the ceaseless extraction of resources, the dispossession of people and poor working conditions. These perspectives follow when the substantive value of pluriversality is invoked. If the practices, institutions and lifestyles that we associate with modernity continue to depend upon and be constituted by coloniality, then these are not compatible with a world in which other worlds fit. It is for this reason that Dussel suggests that decolonial liberation is 'impossible for capitalism' and must not accept the colonial matrix of power 'as a whole' (Dussel, 2013, 138). Though Mignolo primarily presents decoloniality as an option, at other times he suggests that 'pluriversal futures...are only possible if the reign of economic capitalism ends', on the basis that economic capitalism provides space only for practices that can be turned into, or do not obstruct, profits, and hence does not allow different worlds to exist on equal terms (Mignolo, 2011, 292). 
This article is not the place to analyse the validity of Mignolo and Dussel's accounts of capitalism. The point is to suggest that decoloniality should be considered an imperative, and not just an option to be placed on the table. So understood, decolonial global ethics goes beyond a relativism of anything goes. Any option that inevitably depends upon the systematic destruction of other words would violate the principle of a world in which many worlds fit. Decoloniality, and its central value - pluriversality - invoke stringent demands that rule out a number of worlds, practices, and lifestyles. It identifies as wrong a world of economic capitalism if and insofar as it inevitably depends on, and cannot be reformed to prevent, the destruction of other worlds. It identifies as wrong practices of resource extraction, if and insofar as they destroy the livelihoods of peasant and indigenous peoples. It identifies as wrong highly polluting lifestyles, if and insofar as they lead to the destruction of the lives and cosmovisions of those who are dispossessed and displaced as a result of environmental change. It means, finally, that Western civilization as we know it cannot be one legitimate option among many if and insofar as it is constituted through, and cannot be separated from, coloniality.

If decolonial global ethics is to unpick the colonial matrix of power and liberate people(s) from domination, it must be an imperative. It must be understood, as it is by Mignolo $(2011,23)$ in one of his stronger statements, as a project 'which all contending options would have to accept'. This does not mean that decoloniality and pluriversality offer a singular and rigid global design. A pluriversal world is one in which multiple options are possible - a world in which many worlds can co-exist. Whilst other options would be circumscribed insofar as they would have to accept the decolonial imperative of working towards a pluriversal world, this still leaves room for many options, many possible lives, livelihoods and cosmovisions. Only those worlds that involve, inextricably, the continued domination of others are judged as wrong (though it may well be the case that such views should not be excluded from dialogue, given that dialogue itself may help enrich the kind of mutual respect that would lead to the abandonment of such views). Far from invoking a relativism of anything goes, this principle is a demanding one, with radical implications for global social structures and ways of living. The building of a pluriverse is and must be an open-ended project, fed by dialogues amongst actors from across the world. Moreover, the demand of a pluriverse may be impossible to meet fully; in an interconnected world, it may be impossible to ensure that it is not the case that the actions of some constrain the worlds of others. This does not mean, however, that some worlds, practices, livelihoods, lifestyles, and institutional designs are not more compatible with a pluriverse than others. Recognising interconnectedness - and the long history of interconnectedness - only increases the importance of striving for a pluriversal world in an attempt to build a world free from the domination and destruction of the colonial matrix of power.

\section{Conclusion}

Decolonial theory makes a distinctive and valuable contribution to global ethics. It begins with an analysis of coloniality as the inextricable darker side of modernity. In reflecting on what it would mean to decolonise, decolonial theory offers a fundamentally global ethics that is distinct from individualistic and universalistic cosmopolitan theory. It begins with those perspectives threatened by a colonial matrix of power, and proposes inter-cultural dialogue across diverse cosmovisions. In so 
doing, it refuses to specify, in advance, what is of fundamental moral significance. Finally, it embraces pluriversality. Plurversality refers, on the one hand, to a way of constructing values. A value is pluriversal if, rather than being set up as an abstract and already-universal value, it is constructed through dialogue across multiple cosmovisions. Pluriversality also refers to a value of a world in which many words fit. Pluriversality thus offers an account of both a global process through which global values can legitimately be formed, and a value that can be used to judge particular practices, policies, processes, or social structures.

Pluriversality as a value is demanding and judges as morally wrong practices and social structures that inevitably dispossess others. But it is not equivalent to those universal, global designs central to the colonial matrix of power. It is not equivalent, in part, because it embraces radical difference and seeks to multiply options, rather than close them down. It also differs in that it has emerged from, and can only be fleshed out through, a process of pluriversal exchange. Decolonial theory has been constructed alongside and through social movement practice. The above presentation of the value of pluriversality, and of the distinctive features of decolonial theory more broadly, has only been possible in light of the work of peasant, indigenous, feminist and World Social Forum activists contesting various aspects of the colonial matrix of power. Taking decolonial global ethics seriously opens avenues for further work judging whether, how, and why given practices, policies, processes and structures are compatible with pluriversality in both senses of the term. If this article encourages global ethicists to explore further these questions, then it would have played its small part in contributing to the construction of an ethical framework that can take seriously and challenge the legacy of colonial rule.

\section{Bibliography}

Alcoff, Linda Martin. (2012) 'Enrique Dussel's transmodernism', Transmodernity: Journal of Peripheral Cultural Production of the Luso-Hispanic World, 1:3, available at https://escholarship.org/uc/item/58k9k17t, accessed on 19 August 2017

Anievas, Alex and Kerem Nisancioglu. (2015) How the West Came to Rule, London: Pluto.

Archibugi, Daniele and Marchetti, Raphaelle (2009) 'Democratic ethics and UN reform', in Francheschet, Antonio (ed) The Ethics of Global Governance, Boulder, US: Lynne Rienner, 51-66.

Caney, S. (2015) 'Responding to Global Injustice: On the Right of Resistance', Social Philosophy and Policy, 32:1, 51-73, DOI: 10.1017/S0265052515000072.

Castro-Gómez, Santiago. (2007) “The Missing Chapter of Empire: Postmodern Re organization of Coloniality and Post-Fordist Capitalism”, Cultural Studies 21 (2-3): 428-48, DOI: 10.1080/09502380601162639.

Chakrabarty, Dipesh. (2000) Provincializing Europe: Postcolonial Thought and Historical Difference, New Jersey: Princeton University Press. 
Cheah, Pheng. (2006) "The Limits of Thinking in Decolonial Strategies", available at http://townsendcenter.berkeley.edu/publications/limits-thinking-decolonial-strategies, accessed on 18 August 2017.

Conway, Janet and Singh, Jakeet (2009) "Is the World Social Forum a Transnational Public Sphere?” Theory, Culture and Society 26 (5): 61-84, DOI: 0263276409106350. Conway, Janet and Jakeet Singh. (2011) "Radical Democracy in Global Perspective", Third World Quarterly, 32 (4): 689-706, DOI: 10.1080/01436597.2011.570029.

Deveaux, Monique. (2015) “The Global Poor as Agents of Justice”, Journal of Moral Philosophy 12 (2): 125-150, DOI: 10.1163/17455243-4681029.

Deveaux, Monique and Walker, Kathryn. (2013) "Introduction", Journal of Global Ethics 9 (2): 111-114, DOI: 10.1080/17449626.2013.818467.

Dunford, Robin. (2017) "Peasant Activism and the Rise of Food Sovereignty: Decolonising and Democratising Norm Diffusion", European Journal of International Relations 23 (1): 145-167. DOI: 10.1177/1354066115614382.

Dussel, Enrique. (1995) The Invention of the Americas, New York: Continuum.

Dussel, Enrique. (2000) “Europe, Modernity, and Eurocentrism”, Nepantla 1 (3), 465 478, available at http://www.unc.edu/ aescobar/wan/wandussel.pdf, accessed on 19 August 2017.

Dussel, Enrique. (2002) "World-System and Trans-Modernity", Neplanta: Views From the South 3 (2): 221-44, available at https://muse.jhu.edu/article/23955, accessed on 19 August 2017.

Dussel, Enrique. (2012) “Transmodernity and Interculturality: An Interpretation from the Perspective of the Philosophy of Liberation", Transmodernity: Journal of Peripheral Cultural Production of the Luso-Hispanic World 1 (3): 28-59, available at http://escholarship.org/uc/item/6591j76r, accessed on 19 August 2017.

Dussel, Enrique. (2013) Ethics of Liberation, London: Duke University Press.

Escobar, Arturo. (2004) "Beyond the Third World", Third World Quarterly 25 (1), 207-230, DOI: 10.1080/01436590420000185417.

Escobar, Arturo. (2007) "Worlds and Knowledges Otherwise”, Cultural Studies 21 (2-3): 179-210, DOI: 10.1080/09502380601162506.

Frank, Andre-Gunder. (1998) ReOrient: Global Economy in the Asian Age, California: university of California Press.

Grosfoguel, Ramon. (2011) "Decolonizing Post-Colonial Studies and Paradigms of Political Economy", Transmodernity: Journal of Peripheral Cultural Production of 
the

World,

$1(1)$

available

at

http://dialogoglobal.com/texts/grosfoguel/Grosfoguel-Decolonizing-Pol-Econ-and-

Postcolonial.pdf, accessed on 19 August 2017.

Grosfoguel, Ramon. (2012) “Decolonizing Western Uni-versalisms” Transmodernity: Journal of Peripheral Cultural Production of the Luso-Hispanic World 1 (3): 88-104, available at http://escholarship.org/uc/item/01w7163v, accessed on 19 August 2017.

Gudynas, Eduardo. (2011) “Buen Vivir: Today's Tomorrow”, Development, 54 (4), 441-7, DOI: https://doi.org/10.1057/dev.2011.86.

Held, David. (2002) "Law of states: law of peoples", Legal Theory 8 (1): 1-44, DOI: $10.1017 / \mathrm{S} 135232520281016$.

Jahn, Beate. (2013) Liberal Internationalism, London: Palgrave.

Leinius, Johanna. (2014) "Decolonizing Cosmopolitanism in Practice”, CoLLeGIUM

e-series: Helsinki Collegium for Advanced Studies, available at https://helda.helsinki.fi/bitstream/handle/10138/45243/03_LEINIUS_1305.pdf?seque nce $=1$, accessed on 19 August 2017.

Locke, John. (1988) Two Treatises of Government, Cambridge: Cambridge Texts in the History of Political Thought.

Lugones, Maria. (2007) "Heterosexualism and the Colonial/Modern Gender System", Hypatia 22 (1): 186-209, available at https://muse.jhu.edu/article/206329, accessed on 19 August 2017.

Maldonaldo-Torres, Nelson. (2008) Against War, London: Duke University Press.

Martínez-Torres, Elena and Peter Rosset. (2014) "Diálogo de Sabares in La Vía Campesina", The Journal of Peasant Studies 41 (6): 979-997, DOI: 10.1080/03066150.2013.872632.

Marx, Kark. (1906) Capital, Vol. 1, Chicago: Charles H. Kerr.

Metz, Thaddeus. (2014) "Harmonizing Global Ethics in the Future: a Proposal to Add South and East to West", Journal of Global Ethics, 10 (2): 146-55, DOI: $10.1080 / 17449626.2014 .931875$.

Mignolo, Walter. (2000) Local Histories/Global Designs, Princeton: Princeton University Press.

Mignolo, Walter. (2011) The Darker Side of Western Modernity, London: Duke University Press.

Mohanty, Chandra Talpade. (1984) "Under Western Eyes: Feminist Scholarship and Colonial Discourses”, Boundary 212 (3): 333-358, DOI: 10.1057\%2Ffr.1989.1. 
Odysseos, Louiza. (2017) "Prolegomena to Any Future Decolonial Ethics", Millennium, 45 (3): 447-472, DOI: 10.1177/0305829817704503.

Quijano, Anibal. (2007) “Coloniality and Modernity/Rationality”, Cultural Studies 21 (2-3): 168-178, DOI: 10.1080/09502380601164353.

Pagden, Anthony. (2000) "Stoicism, Cosmopolitanism, and the Legacy of European Imperialism”, Constellations, 7 (1): 3-22, DOI: 10.1111/1467-8675.00167.

Pieterse, Jan Nederveen. (2006) "Emancipatory Cosmopolitanism: Towards an Agenda", Development and Change 37: 1247-1257, DOI: 10.1111/j.14677660.2006.00521.

Pogge, Thomas. (1992) “Cosmopolitanism and Sovereignty”, Ethics, 103 (1): 48-75, DOI: $10.1086 / 293470$.

Santos, Boaventura de Sousa, João Arriscado Nunes and Maria Paula Meneses (2007) "Introduction", xix-lxii in Santos, B.S. (ed.) (2007) Another Knowledge is Possible: Beyond Northern Epistemologies, London: Verso.

Sen, Amartya. (2010) The Idea of Justice, London: Penguin.

Waldmüller, Johannes. (2014) "Buen Vivir, Sumak Kawsay, 'Good Living': An Introduction and Overview", Alternautas, available at http://www.alternautas.net/blog/2014/5/14/buen-vivir-sumak-kawsay-good-living-anintroduction-and-overview, accessed on 19 August 2017.

Wai, Zubairu. (2012) "Neo-Patrimonialism and the Discourse of State Failure in Africa", Review of African Political Economy 39: 27-43, DOI: 10.1080/03056244.2012.658719.

Walsh, Caroline. (2010) "Development as Buen Vivir", Development 53 (1): 15-21, DOI: $1011-6370 / 10$.

Weber, Max. (2001) The Protestant Ethic and the Spirit of Capitalism, London: Routledge.

Werbner, Pnina. (2006) "Vernacular Cosmopolitanism", Theory, Culture and Society 23 (2-3): 496-8, DOI: 10.1177/026327640602300291.

Widdows, Heather. (2011) Global Ethics: An Introduction, London: Routledge.

\footnotetext{
i Deveaux and Walker's $(2013,112)$ special issue of the Journal of Global Ethics also 'challenges a central assumption of much mainstream theorizing about global justice, namely, that relations of justice chiefly concern individuals, and should aim to ensure fairness or equity between essentially separate individuals'. They call for a global ethics that is conscious of the legacy of colonialism and that 'endeavors to imagine and reconceive justice using new perspectives, and asking different questions'.
} 
Decolonial global ethics contributes to this project of challenging individualism and drawing on new perspectives.

${ }^{\text {ii }}$ Buen Vivir sometimes refers to a set of state programs and discourses, integrated into the constitutions of and activity of the state in Bolivia and Ecuador, and sometimes to indigenous worldviews and philosophies (see Waldmüller, 2014). To make clear that I am referring to the indigenous worldview, I henceforth use the term Sumak Kawsay.

iii Postcolonial feminist scholarship (i.e., Mohanty, 1984, 335; 351) develops a related critique of the 'ethnocentric universality' of some Western feminist scholarship, claiming that it does not allow 'third world women' to 'rise above their generality and their 'object' status'.

${ }^{\text {iv }}$ Leaving open the question of what is of fundamental moral concern, and of who can participate in inter-cultural dialogue, is important as a means of maintaining the disruptive potential of decolonial ethics. Odysseos $(2017,3)$ argues against moves to formalise decolonial ethics. Instead of "'translating" these important attempts at decolonial ethics into our familiar ethical theories', Odysseos says, we should 'retain decolonial thought's disruption of prevalent figurations, languages and ways of thinking about "ethics"'. By leaving open the question of what is of fundamental moral significance and placing a central emphasis on pluriversal dialogue, decolonial ethics remains open and disruptive, even as it is put into a more formal ethical register.

${ }^{v}$ See, i.e., Santos, Nunes and Meneses, 2007. For an account of the differences between decolonial intercultural dialogue and Habermasian discourse ethics, see Dussel, 2013, 121-140 and Conway and Singh, 2009.

${ }^{\mathrm{vi}}$ My focus, here, is on the tensions within decolonial thought that stem from the dual aspect of the idea of pluriversality. There is insufficient space to address important tensions across decolonial and postcolonial thought. Postcolonial critics of decolonial thought claim that it too talks about the "poor", the "victims" and "Western" ideas, practices and thought in homogeneous terms, and hence fails to do justice to the internal differences within these broad categories. See Cheah, 2006. For a decolonial response, see Alcoff, 2012.

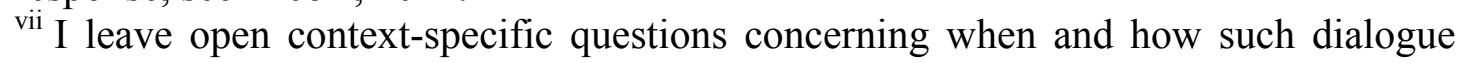
amongst the oppressed should open out to broader dialogue. 